\title{
PERTANGGUNGJAWABAN PEMERINTAH INDIA TERKAIT TINDAKAN PELANGGARAN KEKEBALAN DAN KEISTIMEWAAN YANG DILAKUKAN TERHADAP PERWAKILAN DIPLOMATIK AMERIKA SERIKAT DITINJAU DARI KETENTUAN HUKUM INTERNASIONAL
}

\author{
Aldo Rico Geraldi \\ Dosen Jurusan Ilmu Hukum \\ Fakultas Hukum dan Ilmu Sosial Universitas Pendidikan Ganesha \\ Email: aldoricogeraldi91.com
}

\begin{abstract}
ABSTRAK
Pemerintah India melakukan tindakan pelanggaran terhadap kekebalan dan keistimewaan yang dimiliki oleh perwakilan diplomatik Amerika Serikat di India. Penelitian ini bertujuan untuk menganalisis kekebalan dan keistimewaan yang dimiliki oleh Perwakilan Diplomatik Amerika Serikat. Selain itu juga menganalisis mengenai keabsahan tindakan yang dilakukan, serta bentuk pertanggungjawaban Pemerintah India terhadap Perwakilan Diplomatik Amerika Serikat.

Penelitian ini merupakan penelitian yang menggunakan penelitian hukum normatif dengan mengumpulkan data sekunder. Pengumpulan data dilakukan menggunakan metode studi kepustakaan dengan mengumpulkan bahan hukum dan informasi yang berupa bahan-bahan hukum primer, sekunder, maupun tersier. Dalam rangka mendapatkan pemaparan yang jelas, data tersebut kemudian disusun secara sistematis dan dianalisis dengan menggunakan metode deskriptif.

Hasil penelitian ini menunjukkan bahwa perwakilan diplomatik Amerika Serikat yang ada di India memiliki kekebalan dan keistimewaan sebagaimana yang ditentukan dalam Konvensi Wina 1961 tentang Hubungan Diplomatik. Selanjutnya mengenai pertanggungjawaban atas tindakan Pemerintah India, Pemerintah Amerika Serikat berhak meminta pertanggungjawaban untuk menghentikan pelanggaran yang dilakukan terhadap perwakilan diplomatiknya sebagaimana yang diatur dalam Draft Articles on Responsibility of States for Internationally Wrongful Acts.
\end{abstract}

Kata Kunci: Hubungan Diplomatik, Kekebalan dan Kestimewaan, Pertanggungjawaban.

\section{ABSTRACT}

The Indian government had violated immunities and privileges possessed by the US diplomatic representative in India. This study aimed to analyze the immunity and privileges owned by the US Diplomatic representative. It also analyzes the validity of the actions taken, as well as the form of government accountability of India against the United States Diplomatic representatives.

This research is used normative law research by collecting secondary data. Data is collected using methods of literary study by collecting legal material and information in the form of legal materials of primary, secondary, and tertiary. In order to get a clear 
explanation, the data will be arranged systematically and analyzed using descriptive methods.

The results of this study indicate that the US diplomatic representative in India have immunities and privileges as defined in the 1961 Vienna Convention on Diplomatic Relations. Furthermore, the United States Government has the right to ask for accountability as a part of responsibility upon actions that which taken by the Government of India to US Diplomatic representative in India. US Government requested that India need to stop the abuses committed against diplomatic representation as stipulated in the Draft Articles on Responsibility of States for Internationally Wrongful Acts.

Keywords: Diplomatic Relations, Immunities and Privileges, Accountability.

\section{Pendahuluan}

Hubungan Internasional sangat diperlukan oleh suatu negara dalam rangka berinteraksi dengan negaranegara lain. Pola interaksi hubungan internasional tidak dapat dipisahkan dengan segala bentuk interaksi yang berlangsung dalam pergaulan masyarakat internasional, baik oleh pelaku negara-negara maupun oleh pelaku-pelaku bukan negara (T. May Rudy, 2003:2). Hubungan internasional telah berkembang secara pesat sejak di tandatanganinya Perjanjian West Phalia tahun 1648 (J.G. Starke, 1984;11-12).

Hubungan

diperlukan untuk menunjukkan eratnya hubungan antar negara, hubungan internasional juga merupakan manifestasi sikap saling menghormati yang dilakukan antar negara untuk meningkatkan hubungan yang lebih baik (Masyhur Effendi, 1993:78). Hubungan kerjasama antar negara-negara tersebut biasanya dilakukan dengan membuka hubungan diplomatik dan hubungan konsuler sebagai salah satu instrumen hubungan luar negeri yang merupakan kebutuhan bagi setiap negara (Sumarsono Mestoko, 1988;5).

Hubungan diplomatik menjadi salah satu hal yang penting dalam menjalin hubungan antar negara yang saling bersahabat dengan cara saling menempatkan perwakilan-perwakilan diplomatiknya (R.G. Feltham, 1982;2). Perwakilan diplomatik membutuhkan suatu jaminan keleluasaan untuk bertindak di negara penerima, oleh karena itu hukum internasional melalui Konvensi Wina 1961 tentang Hubungan Diplomatik (Vienna Convention on Diplomatic Relations, 1961. Selanjutnya disebut Konvensi Wina Tahun 1961 tentang Hubungan Diplomatik.), memberikan jaminan kepada perwakilan diplomatik berupa hak kekebalan dan hak istimewa. Hak kekebalan dan keistimewaan yang diperoleh oleh perwakilan diplomatik agar dapat menjalankan misinya secara bebas dan aman, diberikan atas dasar timbal balik antara negara-negara yang mengadakan hubungan.

Pasal 31 Konvensi Wina 1961 tentang Hubungan Diplomatik mengatur mengenai perlindungan bagi pejabat diplomatik menyatakan " $A$ 
diplomatic agent shall enjoy immunity from the criminal jurisdiction of the receiving State. He shall also enjoy immunity from its civil and administrative jurisdiction". Pejabat diplomatik harus kebal dari kekuasaan hukum pidana negara penerima. Ia juga kebal dari kekuasaan hukum perdata dan acara. Meskipun pengaturan mengenai kekebalan pejabat diplomatik telah diatur secara tegas pada Konvensi Wina 1961 tentang Hubungan Diplomatik, namun pada pelaksanaannya masih banyak terjadi pelanggaran yang dilakukan oleh negara penerima terhadap perwakilan diplomatik negara pengirim.

Salah satu bentuk pelanggaran terhadap perlindungan kekebalan dan keistimewaan diplomatik sebagaimana tindakan yang dilakukan oleh Pemerintah India terhadap perwakilan diplomatik Amerika Serikat di India. Pemerintah India melakukan tindakan tegas seperti meminta semua perwakilan diplomat Amerika Serikat yang ditempatkan di India untuk menyerahkan kartu identitas dan juga mencabut beberapa hak istimewa (Australia Network News, 18 Desember 2013). Tindakan lainnya yang dilakukan oleh Pemerintah India yaitu menarik barikade polisi yang berada di luar kedutaan besar Amerika Serikat di New Delhi dan melepas labirin keamanan yang dimaksudkan untuk melindungi kantor kedutaan, serta akses bagi staf diplomatik Amerika Serikat ke bandar udara juga dibatasi (New York Times, 20 Desember 2014).

Pemerintah India melakukan hal tersebut dikarenakan tindakan Pemerintah Amerika Serikat yang telah melakukan penangkapan terhadap seorang pejabat Konsuler India di New York (Washington Post, 14 Maret 2014). Agen khusus biro keamanan diplomatik Amerika Serikat menangkap Devyani Khobragade yang merupakan wakil Konsul Jenderal India di New York untuk urusan politik, ekonomi, komersial dan perempuan, dengan tuduhan penipuan atau penyalahgunaan visa dan membuat pernyataan atau dokumen palsu untuk tujuan merekrut seorang warga India yaitu Sangeeta Richard untuk bekerja sebagai pembantu rumah tangga di rumahnya (The Times of India, 19 Desember 2013).

\section{Rumusan Masalah}

Berdasarkan latar belakang yang telah diuraikan di atas, penulis mengangkat dua permasalahan yang meliputi:

1. Bagaimana kekebalan dan keistimewaan yang dimiliki oleh Perwakilan Diplomatik Amerika Serikat?

2. Bagaimana pertanggungjawaban Pemerintah India terhadap Perwakilan Diplomatik Amerika Serikat?

\section{Metode Penelitian}

Penelitian ini merupakan penelitian hukum normatif dengan mengkaji suatu aturan-aturan, prinsipprinsip, dan doktrin-doktrin hukum yang terkait dengan permasalahan dalam penelitian ini untuk menghasilkan suatu argumentasi. Selain itu, penelitian ini juga mengkaji latar belakang dari pengaturan mengenai isu yang dihadapi. Selanjutnya bahan hukum terkumpul 
kemudian dianalisis menggunakan teknik deskriptif dengan memaparkan bahan hukum primer, bahan hukum sekunder dan bahan hukum tersier (Ronny Hanitijo, 1991;93).

\section{Pembahasan}

\section{Tanggung Jawab Negara dalam Hukum Internasional}

Prinsip kedaulatan negara dalam hubungan internasional sangatlah dominan. Negara berdaulat yang satu tidak tunduk pada negara berdaulat yang lain (Sefriani, 2010:265-266). Negara mempunyai kedaulatan penuh atas orang, barang dan perbuatan yang ada di teritorialnya (Ibid:266). Negara dikatakan berdaulat karena kedaulatan merupakan suatu sifat atau ciri hakiki negara (Mochtar Kusumaatmadja dan Etty R. Agoes, 2010:16). Hukum internasional telah mengatur bahwa di dalam kedaulatan terkait di dalamnya kewajiban untuk tidak menyalahgunakan kedaulatan tersebut (Sefriani, loc.cit). Suatu negara berdaulat pada hakekatnya tunduk pada dan menghormati hukum internasional (I Wayan Parthiana, 2003:90).

Kedaulatan yang dimiliki oleh suatu negara tidaklah berarti bahwa negara tersebut bebas dari tanggung jawab. Prinsip yang juga berlaku terhadapnya sebagaimana yang dijelaskan sebelumnya bahwa di dalam kedaulatan terkait di dalamnya kewajiban untuk tidak menyalahgunakan kedaulatan tersebut, oleh karena itu suatu negara dapat dimintakan pertanggungjawaban untuk tindakan-tindakannya yang melawan hukum atau karena kelalaiannya
(Sefriani, loc.cit). Setiap pelanggaran terhadap hak negara lain, menyebabkan negara tersebut wajib untuk memperbaiki pelanggaran hak tersebut (Malcom N. Shaw, 1997:541). Dengan kata lain, negara tersebut harus mampu untuk mempertanggungjawabkannya (Huala Adolf, 1991:173).

Pertanggungjawaban berarti kewajiban memberikan jawaban yang merupakan perhitungan atas suatu hal yang terjadi dan kewajiban untuk memberikan pemulihan atas kerugian yang mungkin ditimbulkannya (F. Sugeng Istanto, 1998:77). Kaidahkaidah hukum internasional mengenai tanggung jawab negara menyangkut keadaan-keadaan, prinsip-prinsip negara yang dirugikan menjadi berhak atas ganti rugi untuk kerugian yang dideritanya (T. May Rudy, 2002:83). Selain itu, tanggung jawab negara muncul sebagai akibat dari prinsip persamaan dan kedaulatan negara yang terdapat dalam hukum internasional. Tanggung jawab negara telah dinyatakan secara tegas dibatasi pada pertanggungjawaban negaranegara bagi tindakan-tindakan yang secara internasional tidak sah (T. May Rudy, loc.cit). Ini merupakan tanggung jawab negara dalam arti tegas, sumber dari tanggung jawab tersebut adalah suatu tindakan atau tindakan-tindakan yang melanggar hukum internasional (J.G. Starke, 2008:391).

Pertanggungjawaban negara biasanya muncul karena diakibatkan oleh pelanggaran atas hukum internasional. Selain itu, suatu negara dikatakan bertanggungjawab dalam hal negara tersebut melakukan 
pelanggaran atas perjanjian internasional (Martin Dixton and Robert McCorquodale, 2003:404), melanggar kedaulatan wilayah negara lain, menyerang negara lain, mencederai perwakilan negara lain, bahkan memperlakukan warga asing dengan seenaknya (Jawahir Thontowi dan Pranoto Iskandar, 2006:194). Oleh karena itu, pertanggungjawaban negara memiliki kadar yang berbedabeda tergantung pada kewajiban yang diembannya atau besar kecilnya kerugian yang telah ditimbulkan (Ibid). Selain itu, para pakar hukum internasional juga mengemukakan beberapa karakteristik timbulnya tanggung jawab negara, seperti (Malcom N. Shaw, op.cit: 482):

1. Adanya suatu kewajiban hukum internasional yang berlaku antara dua negara tertentu;

2. Adanya suatu perbuatan atau kelalaian yang melanggar kewajiban hukum internasional tersebut yang melahirkan tanggung jawab negara;

3. Adanya kerusakan atau kerugian sebagai akibat adanya tindakan yang melanggar hukum atau kelalaian.

Meskipun belum mendapatkan kesepakatan secara universal, karakteristik tersebut banyak diikuti dalam hukum internasional. Tanggung jawab negara hanya bisa dituntut dalam hubungan internasional ketika ada suatu negara yang dirugikan oleh negara lain akibat pelanggaran kewajiban atau kelalaian yang muncul dari perjanjian, hukum kebiasaan internasional, atau akibat tidak memenuhinya kewajiban yang muncul dari putusan pengadilan (Martin Dixon, 2000:232). Dalam persoalan tanggungjawab negara, suatu negara penuntut berhak atas ganti rugi apabila tuntutannya telah dibenarkan, terlepas dari apakah tindakan melawan hukum yang menjadi pokok tuntutan itu menyebabkan kerugian material (J.G. Strarke, op.cit:421). Mengutip Permanent Court of International Justice dalam Chorzow Factory (Indemnity) Case, bahwa kerugian yang diderita oleh seorang individu tidak pernah identik macamnya dengan kerugian yang mungkin diderita oleh suatu negara, kerugian itu hanya menghasilkan suatu skala yang memuaskan untuk perhitungan ganti rugi yang diberikan kepada negara tersebut (T. May Rudy, op.cit:91).

Kesalahan atau kerugiankerugian yang menimbulkan tanggungjawab negara mungkin beragam jenisnya. Dengan demikian, suatu negara bertanggung jawab karena melanggar perjanjian, berkaitan dengan tidak dilaksanakannya kewajiban-kewajiban kontraktual, karena kerugian-kerugian terhadap warga negara dari negara lain dan sebagainya (J.G. Strarke, op.cit:392). Tanggung jawab negara diatur oleh standar-standar internasional meskipun dalam pelanggaran khusus suatu standar internasional dapat memasukkan suatu standar nasional, dan hal itu bergantung pada hukum internasional mengenai apakah dan sejauh mana tindakan atau kelalaian dari suatu negara tertentu dianggap sah atau tidak sah (Ibid).

Apabila tindakan-tindakan atau kelalaian-kelalaian suatu negara yang diukur oleh standar-standar tersebut dinyatakan sah, maka tanggung jawab 
negara tidak akan timbul. (Sefriani, op.cit:268). Demikian pula halnya apabila hukum internasional mengakui yurisdiksi suatu negara yang melakukan tindakan itu, maka tidak ada pelanggaran kewajiban yang menimbulkan tanggung jawab dari negara tersebut (J.G. Starke, op.cit.:392). Adapun yang merupakan unsur-unsur dari suatu tindakan yang salah adalah adanya tindakan (action) atau pengabaian (omission) yang dapat dilimpahkan atau diatribusikan kepada negara menurut hukum internasional (Sefriani, op.cit:270). Unsur dapat dilimpahkan muncul karena dalam praktik, negara sebagai suatu entitas yang abstrak tidak dapat bertindak sendiri, harus melalui individu sebagai organ negara, perwakilan negara, atau pejabat negara (Mohamad Burhan Tsani, 1990:48).

Tindakan negara yang dapat dilimpahkan adalah tindakan dari semua organ negara (state organ), baik legislatif, eksekutif, yudikatif atau apapun fungsinya, apapun posisinya dalam struktur organisasi negara dan apapun karakternya sebagai organ pemerintah pusat atau territorial unit dari suatu negara. Termasuk dalam organ adalah setiap orang atau kesatuan (entity) yang mempunyai status organ negara dalam hukum nasional (Pasal 4 Draft articles on Responsibility of State for Internationally Wrongful Acts). Selanjutnya adalah tindakan individu atau entity yang meskipun bukan organ negara atau diluar struktur formal pemerintah pusat atau daerah, tetapi dikuasakan secara sah untuk melaksanakan unsur-unsur kekuasaan instansi tertentu pemerintah (Pasal 5 Draft articles on Responsibility of State for Internationally Wrongful Acts).

Tindakan organ negara atau orang atau kesatuan yang dikuasakan oleh elemen pemerintah sebagaimana yang dikemukakan di atas dalam kapasitas resminya dipandang sebagai tindakan negara dan dapat dilimpahkan, bahkan jika mereka di luar kekuasaannya (exceeds its authority) atau melakukan tindakan yang bertentangan dengan instruksi yang diberikan padanya (contravention of instruction) (Pasal 7 Draft articles on Responsibility of State for Internationally Wrongful Acts). Tindakan individu atau kelompok dianggap sebagai tindakan negara bila dalam melakukan tindakannya mereka mendapat instruksi, atau dibawah petunjuk atau kontrol negara (Pasal 8 Draft articles on Responsibility of State for Internationally Wrongful Acts).

Negara bertanggung jawab untuk memberikan perbaikan terhadap kerugian yang ditimbulkan oleh the internationally wrongful acts (Sefriani, op.cit:272-273). Kerugian yang dimaksud meliputi material, immaterial yang disebabkan oleh the internationally wrongful acts negara tersebut (Pasal 31 dan Pasal 36 Draft articles on Responsibility of State for Internationally Wrongful Acts). Tanggung jawab negara bersifat melekat pada negara (Sefriani, op.cit:273). Perbaikan terhadap kerugian yang disebabkan oleh the internationally wrongful acts dapat dalam bentuk restitusi, kompensasi, penghukuman terhadap orang-orang yang seharusnya bertanggung jawab, 
permintaan maaf, atau pemuasan (satisfaction) atau kombinasi dari kesemuanya (Ibid).

Dalam kaitannya dengan kompensasi yang berwujud materi dapat terdiri dari penggantian biaya pada waktu putusan pengadilan dikeluarkan meskipun jumlah penggantian itu menjadi lebih besar dari nilai pada waktu tindakan pelanggaran kewajiban itu dilakukan (Rhoona K.M Smith dkk, 2008:80). Selain itu, dapat juga terdiri dari kerugian tidak langsung (indirect demages), sepanjang kerugian itu mempunyai kaitan langsung dengan tindakan tidak sah tersebut (Sefriani, op.cit:274). Selanjutnya, dapat juga terdiri dari hilangnya keuntungan yang diharapkan sepanjang keuntungan tersebut mungkin dalam situasi atau dalam perkembangan yang normal, serta terdiri dari pembayaran terhadap kerugian atas bunga yang hilang karena adanya tindakan melanggar hukum (Rhoona K.M Smith dkk, loc.cit).

Draf articles on Responsibility of State for Internationally Wrongful Acts tentang tanggung jawab negara banyak membawa perkembangan baru bagi hukum tanggung jawab negara dalam hukum internasional (Jahawir Thontowi dan Pranoto Iskandar, 2006:198: Sefriani, $\quad$ loc.cit). Perkembangan baru tersebut khususnya menyangkut siapa yang dapat mengajukan tuntutan tanggung jawab negara. Draf articles on Responsibility of State for Internationally Wrongful Acts tentang tanggung jawab negara terdiri dari 4 bagian dan 59 pasal. Bagian pertama mengenai The Internationally wrongful act of a state, kedua mengenai Content of the International Responsibility of state, ketiga mengenai The implementation of the International Responsibility of a State, dan keempat mengenai General Provision (Draft articles on Responsibility of State for Internationally Wrongful Acts). Jika hukum internasional klasik hanya memberikan hak pada negara yang dirugikan saja untuk menuntut tanggung jawab negara, maka Draft ILC 2001 tentang tanggung jawab negara membedakan antara negara yang dirugikan (injured states) yang diatur pada Pasal 42 dan negara yang tidak dirugikan (noninjured states) sebagaimana yang diatur pada Pasal 48 ayat (1) Draf articles on Responsibility of State for Internationally Wrongful Acts (Lihat Pasal 42 Draft articles on Responsibility of State for Internationally Wrongful Acts).

Pasal 42 Draf articles on Responsibility of State for Internationally Wrongful Acts ini mirip dengan Pasal 60 Konvensi Wina 1969 tentang Perjanjian Internasional, berhubungan dengan material breaches of treaties. Pasal 42 huruf a menetapkan bahwa suatu negara dirugikan ketika ada pelanggaran kewajiban individual. Hal ini terjadi pada berbagai perjanjian bilateral, komitmen sepihak seperti komitmen untuk tidak menggunakan jenis senjata tertentu, tidak menangkap ikan di zona tertentu, ketentuan umum hukum internasional yang melahirkan kewajiban tertentu antar dua negara seperti perjanjian multilateral yang melahirkan kewajiban-kewajiban tertentu satu sama lain. Pasal 42 huruf 
b juga menetapkan bahwa diterapkan dalam hal suatu negara di pengaruhi oleh pelanggaran kewajiban hukum internasional oleh pihak lain. Negara yang dirugikan ketika meminta tanggung jawab dari negara lain, memberitahukan tuntutannya pada negara tersebut supaya negara tersebut menghentikan tindakan pelanggarannya jika hal tersebut masih berlangsung. Negara yang dirugikan juga dapat menyertakkan dalam tuntutannya bentuk pemulihan yang dituntut dari negara pelanggar.

Berdasarkan Pasal 48 ayat (1) Draft Articles on the Responsibility of States for International Acts, negaranegara selain negara yang dirugikan dapat mengajukan tuntutan pertanggungjawaban pada negara lain dalam dua hal. Pertama yaitu kewajiban yang dilanggar dimiliki suatu kelompok negara termasuk negara yang mengajukan tuntutan tersebut, ditetapkan untuk perlindungan kepentingan kelompok tersebut. Ketentuan ini mencakup perjanjian-perjanjian regional di bidang keamanan, perlindungan HAM, dan lingkungan. Hal ini sesuai dengan tanggung jawab negara dalam S.S Wembledon Case. Dalam kasus ini ketika Jerman menolak mengizinkan British Vessel yang disewa perusahaan Prancis untuk berlayar di The Kiel Canal, Inggris, Prancis, Italia, dan Jepang menuntut Jerman untuk pelanggaran The Treaty of Versailles. Mahkamah Internasional Permanen mengakui hak negara-negara pemohon dengan dasar bahwa mereka memiliki kepentingan hukum, sebagai negara pihak dalam Versailles Treaty, memiliki kapal yang senantiasa melalui The Kiel Canal, meskipun Italia dan Jepang tidak memiliki kepentingan ekonomi langsung terhadap kasus ini (Sefriani, op.cit:278). Kedua, kewajiban yang dilanggar dimiliki oleh seluruh masyarakat internasional secara keseluruhan (erga omnes). Komisi penyusunan draft merujuk pada putusan Mahkamah Internasional dalam kasus Barcelona yang membedakan antara kewajiban yang dimiliki negara tertentu dengan yang menyangkut masyarakat internasional keseluruhan. Dalam hal yang kedua ini masyarakat internasional keseluruhan mempunyai hak mengajukan tuntutan terhadap negara pelanggar. Masuk kategori dimana masyarakat internasional mempunyai hak ini adalah kewajiban yang berkaitan dengan perlindungan HAM dan lingkungan. Contoh di bidang HAM antara lain masalah genocida, perbudakan, diskriminasi rasial dan penentuan nasib sendiri. Adapun di bidang lingkungan adalah larangan to dispose high-or-medium level nuclear wastes di lautan (Ibid:278-279).

Selanjutnya Pasal 48 ayat (2) menetapkan bahwa setiap negara yang berhak untuk meminta pertanggungjawaban dari negara lain tidak hanya berhak meminta penghentian tindakan pelanggaran serta jaminan tidak mengulangi, tetapi juga berhak atas pemulihan kepentingan-kepentingan negara yang dirugikan dari kewajiban yang dilanggar. Pasal 49 Draft Articles on the Responsibility of States for International Acts juga mengatur mengenai tindakan pembalasan yang hanya dapat 
dilakukan oleh suatu negara terhadap negara yang melakukan internationally wrongful act untuk memaksa negara tersebut melaksanakan kewajibannya (Pasal 49 ayat (1) Draft articles on Responsibility of State for Internationally Wrongful Acts). Pembalasan tidak mempengaruhi kewajiban negara untuk menahan diri dari ancaman atau penggunaan kekerasan sebagaimana diatur dalam Piagam PBB, kewajiban perlindungan HAM yang fundamental, kewajiban $a$ humanitarian character prohibiting reprisals, dan kewajiban lain di bawah norma dasar hukum kebiasaan internasional (Pasal 50 ayat (1) Draft articles on Responsibility of State for Internationally Wrongful Acts).

Pembalasan yang dilakukan suatu negara terhadap negara yang lain juga harus tetap menghormati prinsip tidak dapat diganggu gugatnya agen-agen diplomatik dan konsuler, gedung, arsip serta dokumen perwakilan asing (Pasal 50 ayat (2) huruf b Draft articles on Responsibility of State for Internationally Wrongful Acts). Pembalasan juga harus dilakukan secara proposional sesuai dengan kerugian yang diderita dan bobot pelanggaran kewajiban yang dipermasalahkan (Pasal 51 Draft articles on Responsibility of State for Internationally Wrongful Acts). Pembalasan harus dihentikan sesegera mungkin setelah negara pelanggar melaksanakan kewajibannya (Pasal 53 Draft articles on Responsibility of State for Internationally Wrongful Acts). Selanjutnya, Pasal 54 membatasi hak negara-negara yang berhak meminta pertanggungjawaban negara lain berdasarkan Pasal 48 ayat (1) dengan lawful measures (Pasal 54 Draft articles on Responsibility of State for Internationally Wrongful Acts). Berdasarkan ketentuan-ketentuan tersebut, Draf articles on Responsibility of State for Internationally Wrongful Acts hanya mengatur prinsip-prinsip umum tanggung jawab negara, dan tidak mengatur hal-hal tertentu secara khusus (Martin Dixon, op.cit::230).

\section{Kekebalan dan Keistimewaan Perwakilan Diplomatik Amerika Serikat}

Pejabat diplomatik Amerika Serikat yang berada di India untuk melaksanakan tugasnya memiliki kekebalan dan keistimewaan diplomatik sebagaimana yang telah diatur pada Konvensi Wina 1961 tentang Hubungan Diplomatik. Kekebalan dan keistimewaan tersebut telah diterima sebagai praktik negaranegara dan bahkan telah diterima oleh para ahli hukum internasional meskipun jika terbukti bahwa pejabat diplomatik tersebut telah terlibat dalam komplotan atau penghianatan melawan kedaulatan negara penerima (Sumaryo Suryokusumo, 2005:50).

Prinsip untuk memberikan kekebalan dan keistimewaan telah dilakukan oleh negara atas dasar timbal balik (Kishan S. Rana, 2013:110), hal tersebut diperlukan untuk menjamin agar perwakilan atau misi asing di suatu negara dapat menjalankan tugas misinya secara bebas dan aman (Paul Sharp, 2009:43). Dalam hukum internasional, pemberian kekebalan dan 
keistimewaan diplomatik dikenal dengan beberapa teori, antara lain:

\section{Exterririality Theory}

Menurut teori tersebut, seorang pejabat diplomatik dianggap tidak berada di negara penerima melainkan berada dalam negara pengirim, meskipun kenyataannya ia berada di wilayah negara penerima (Grant V, McClanahan, 1989:30). Maksudnya, seorang diplomat tidak tunduk pada yurisdiksi hukum nasional setempat yang sebenarnya teori ini menghendaki bahwa setiap pejabat diplomatik hanya dikuasai oleh hukum negara pengirim. Sementara itu, kantor perwakilan dan tempat kediamannya dianggap sebagai bagian dari wilayah negara pengirim (Setyo Widagdo dan Hanif Nur Widhiyanti, 2008:73).

2. Representative Character Theory Menurut teori tersebut, diplomat dianggap sebagai simbol atau lambang negara pengirim sekaligus wakil negara pengirim di negara penerima (Syahmin, 2008:117). Oleh karena itu, segala perbuatan diplomat harus dianggap sebagai perbuatan dari kepala negara atau setidaknya dianggap sebagai pencerminan kehendak negara pengirim (J. G. Starke, 2007:566). Berdasarkan hal tersebut, setiap diplomat perlu mendapat kekebalan dan keistimewaan agar dapat melaksanakan tugas secara baik (Setyo Widagdo dan Hanif Nur Widhiyanti, op.cit:77). Pemberian kekebalan dan keistimewaan dianggap sebagai konsekuensi logis dari anggapan bahwa diplomat merupakan wakil dari kepala negara atau wakil negara yang berdaulat (Widodo 2, 2012:119).

\section{Funcional Necessity Theory}

Menurut teori tersebut, kekebalan dan keistimewaan diplomatik perlu diberikan kepada diplomat agar dapat melaksanakan fungsinya secara optimal, sehingga hasil pekerjaannya memuaskan negara penerima dan negara pengirim (Veronica L. Maginnis, 2008:2). Dengan memberikan tekanan pada kepentingan fungsi, terbuka jalan bagi pembatasan hak kekebalan dan keistimewaan sehingga dapat diciptakan keseimbangan antara kebutuhan negara pengirim dan hak-hak negara penerima (Syahmin, op.cit:118).

Konvensi Wina 1961 tentang Hubungan Diplomatik menjelaskan bahwa setiap orang yang berhak mendapat kekebalan dan hak-hak istimewa akan mulai menikmatinya semenjak ia memasuki wilayah negara penerima, dalam perjalanannya untuk memangku jabatannya, atau jika ia sudah berada di wilayah negara penerima, dan mulai menikmatinya sejak pengangkatannya diberitahukan kepada kementerian luar negeri atau kepada kementerian lainnya sebagaimana yang telah disetujui (Zainab Waheed Dahham, 2013:4; Setyo Widagdo dan Hanif Nur Widhiyanti, op.cit::83-84). Sedangkan mengenai berakhirnya kekebalan dan hak-hak istimewa dari seorang wakil diplomatik asing yaitu pada saat masa jabatannya atau tugas-tugasnya telah berakhir, biasanya pada saat ia meninggalkan negara atau pada saat 
berakhirnya suatu waktu yang layak atau kesempatan yang layak yang diberikan kepadanya untuk meninggalkan negara penerima (Paul Gully-Hart, 1999:1339). Pejabat diplomatik juga menikmati kekebalan dan keistimewaan yang dimilikinya apabila berada di negara ketiga (G.R. Berridge, dkk, 2001:62). Negara ketiga memberikan kekebalan dan keistimewaan atau hak melintas secara bebas terhadap para diplomatik pada waktu transit, kecuali bagi mereka yang berpergian secara incognito atau kehadiran mereka di wilayah negara ketiga tidak diinginkan (Setyo Widagdo dan Hanif Nur Widhiyanti, op.cit:93).

Apabila seorang pejabat diplomatik melalui atau berada di wilayah negara ketiga yang telah memberikan visa, apabila visa demikian diperlukan dalam perjalanan menuju ke atau kembali ke tempat penugasan ataupun ketika kembali ke negerinya sendiri, maka negara ketiga itu harus memberikan kepadanya hak untuk tidak diganggu gugat dan kekebalan-kekebalan lain yang mungkin diperlukan untuk menjamin perjalanan transit atau perjalanan kembali (Pasal 40 ayat (1) Konvensi Wina 1961 tentang Hubungan Diplomatik). Hal yang sama berlaku pula terhadap anggota keluarga para diplomat yang bersangkutan, anggota staf administrasi dan teknik serta pembantu perwakilan diplomatik yang menyertai atau berpergian secara terpisah untuk bergabung dengannya atau dalam perjalanan kembali ke negaranya (Pasal 40 ayat (1) dan ayat (2) Konvensi Wina 1961 tentang Hubungan Diplomatik).
Negara penerima harus menjamin semua anggota misi untuk bebas bergerak dan berpergian di wilayah negaranya (Widodo 1, 2009:133). Selain itu, negara penerima harus mengizinkan dan melindungi komunikasi yang bebas bagi perwakilan untuk semua keperluan dinas (Sumaryo Suryokusumo, op.cit::70), surat menyurat resmi dari perwakilan tidak boleh diganggu gugat (A. Masyhur Effendi, op.cit:86), kantong diplomatik tidak boleh dibuka atau ditahan (Rosalyn Higgins, 2006:1), barang-barang yang terdapat pada kantong diplomatik harus diberi tanda sehingga terlihat dari luar dan hanya boleh berisi dokumen-dokumen diplomatik atau barang-barang untuk keperluan resmi (Gergo Pasqualetti, 2012:46). Kurir diplomatik harus dilengkapi dengan dokumen resmi sehingga negara penerima harus melindungi dan kurir tersebut tidak dapat diganggu gugat serta tidak boleh dikenakan segala bentuk penangkapan dan penahan (Syahmin, op.cit:147). Selanjutnya, negara pengirim atau perwakilannya dapat menunjuk kurirkurir diplomatik ad hoc (sementara) (Monika Lozancic, 2009:42), dan kantong diplomatik tersebut dapat dititipkan pada kapten suatu pesawat terbang yang harus dilengkapi dengan suatu dokumen resmi, tetapi kapten pesawat tersebut tidak diakui sebagai seorang kurir diplomatik (Setyo Widagdo dan Hanif Nur Widhiyanti, op.cit:123).

Seorang pejabat diplomatik tidak dapat diganggu gugat sehingga ia tidak dapat ditahan atau ditangkap oleh alatalat negara penerima (Neo Cornago, 
2013:162). Negara penerima harus memperlakukan mereka secara terhormat, dan apabila perlu alat-alat negara penerima wajib mengambil segala tindakan yang tepat untuk mencegah setiap serangan terhadap jiwa dan raga pejabat diplomatik, termasuk mencegah serangan yang berakibat pada pelecehan martabat dan penghambatan kebebasan (The United States Department of State Bureau of Diplomatic Security, URL: http://www.state.gov/documents/org anization/150546.pdf). Kediaman pribadi pejabat diplomatik juga tidak boleh diganggu gugat dan harus memperoleh perlindungan seperti halnya dengan gedung perwakilan (Pasal 30 ayat (1) Konvensi Wina 1961 tentang Hubungan Diplomatik). Surat menyurat resmi dan harta miliknya juga tidak boleh diganggu gugat (Pasal 30 ayat (2) Konvensi Wina 1961 tentang Hubungan Diplomatik).

Kekebalan terhadap yurisdiksi pengadilan pidana yang dapat dinikmati oleh para pejabat diplomatik ditentukan di dalam Konvensi Wina 1961 tentang Hubungan Diplomatik, bahwa seorang pejabat diplomatik kebal dari yurisdiksi kriminal atau pidana dari negara penerima (Tariq Hassan, 2011:24). Alat-alat kekuasaan negara penerima tidak boleh menangkap, menuntut, atau mengadili seseorang pejabat diplomatik di dalam suatu perkara kriminal atau pidana (Setyo Widagdo dan Hanif Nur Widhiyanti, op.cit:106-107). Selanjutnya, Konvensi Wina 1961 tentang Hubungan Diplomatik mengatur bahwa negara penerima boleh setiap saat dan tanpa harus menerangkan keputusannya, memberitahu negara pengirim bahwa kepala misinya atau seorang staf diplomatiknya adalah persona nongrata atau anggota lainnya dari staf tersebut tidak dapat diterima (Edy Suryono, 1992:48). Namun, harus dipahami bahwa tindakan pengusiran atau persona nongrata ini hanya dapat diadakan oleh negara penerima di dalam hal atau keadaan yang sangat terpaksa (Widodo 1, op.cit.:79).

Dengan demikian, apabila seorang pejabat diplomatik membuat kesalahan yang dapat mengganggu keamanan dan ketertiban dalam negeri atau turut dalam suatu komplotan yang ditujukan kepada negara penerima, melakukan campur tangan terhadap urusan dalam negeri negara penerima dan tidak memperhatikan hukumhukum dan peraturan-peraturan negara penerima yang mengancam kewibawaan pemerintah, maka negara penerima berdasarkan Pasal 41 ayat (1) dan Pasal 9 Konvensi Wina 1961 dapat mengusir atau menyatakan persona non grata pada pejabat diplomatik tersebut (Setyo Widagdo dan Hanif Nur Widhiyanti, op.cit:107).

Hukum kebiasaan internasional tidak saja memberikan kekebalan dari yurisdiksi pidana negara penerima, tetapi juga para pejabat diplomatik kebal dari yurisdiksi perdata dan administrasi (Yuliya G. Zabyelina, 2013:2). Ketentuan yang mengatur adanya kekebalan seorang pejabat diplomatik dari yurisdiksi perdata atau sipil terdapat dalam ketentuan Pasal 31 ayat (1) Konvensi Wina 1961 tentang Hubungan Diplomatik (Tariq Hassan, loc.cit). Tuntutan perdata dan 
administrasi dalam bentuk apapun tidak dapat dilakukan terhadap seseorang pejabat diplomatik dan tidak ada tindakan atau eksekusi apapun yang berhubungan dengan hutanghutang dan lain-lainnya yang serupa dapat diajukan terhadap para pejabat diplomatik didepan pengadilan perdata atau pengadilan administrasi negara penerima (Setyo Widagdo dan Hanif Nur Widhiyanti, op.cit:110). Para pejabat diplomatik juga tidak dapat ditangkap karena hutang-hutang mereka, juga terhadap alat perkakas rumah tangga mereka, kendaraan bermotor dan lain-lainnya yang mereka miliki tidak dapat disita untuk membayar hutangnya (Edy Suryono, op.cit:49).

Pejabat diplomatik yang pergi untuk meninggalkan wilayah negara tersebut tidak dapat dihalang-halangi walaupun dengan alasan mereka belum melunasi hutang-hutangnya dan paspornya juga tidak dapat ditahan dengan alasan yang sama (Setyo Widagdo dan Hanif Nur Widhiyanti, loc.cit). Namun tidak seperti di dalam kekebalan terhadap yurisdiksi pidana, dimana seorang pejabat diplomatik secara mutlak tidak dapat diajukan di depan pengadilan negara penerima atas kesalahan-kesalahan mereka (Ibid). Dalam hal kekebalan diplomatik terhadap yurisdiksi sipil tidak secara mutlak berlaku. Dalam hal ini ada beberapa pengecualian, yaitu terkait dengan suatu tindakan nyata yang berhubungan dengan harta kekayaan tak bergerak milik pribadi yang terletak di negara penerima, kecuali harta milik tersebut dikuasai atas nama negara pengirim untuk keperluan perwakilan (Emily F. Siedell, 2011:176; Syahmin, 1988:82).

Pengecualian tersebut juga berlaku terhadap suatu tindakan nyata yang berhubungan dengan suksesi, dimana pejabat diplomatik tersebut terlibat sebagai eksekutor/penyita, administrator/penguasa, ahli waris atau legataris sebagai perorangan dan tidak atas nama negara pengirim (Widodo 2, op.cit:144). Selain itu, terkait dengan suatu tindakan yang berhubungan dengan setiap kegiatan profesional atau perdagangan komersial yang dilakukan oleh pejabat diplomatik di dalam negara penerima dan diluar fungsi resminya (Amy Tai, 2007:193-194; Edy Suryono, op.cit:50). Selanjutnya, pejabat diplomatik tidak diwajibkan untuk memberikan kesaksian atas apapun yang mereka ketahui di pengadilan negara penerima (Syahmin, op.cit:129). Para anggota keluarga pejabat diplomatik yang tinggal di negara penerima dan menjadi anggota rumah tangganya, temasuk pengikutpengikutnya juga tidak dapat dipaksa untuk menjadi saksi di depan pengadilan negara penerima sehubungan dengan apa yang mereka ketahui (Setyo Widagdo dan Hanif Nur Widhiyanti, op.cit:113).

Dengan demikian, pembebasan ataupun kekebalan diplomatik terhadap yurisdiksi sipil yang dinikmati oleh seorang wakil diplomatik asing tidak diperluas dalam hal tindakan-tindakan yang berhubungan dengan harta benda yang tidak bergerak dan dimiliki atau dikuasi oleh seseorang wakil diplomatik dalam kedudukannya 
sebagai seorang individual (pribadi) dan tidak dalam kedudukannya yang resmi (Ibid:112). Selain itu, pengadilan negara penerima berwenang mengadili perkara-perkara yang timbul mengenai harta benda atau hak milik yang berhubungan dengan kegiatankegiatan perdagangan (Ibid). Berdasarkan ketentuan Pasal 31 Konvensi Wina 1961 tentang Hubungan Diplomatik, dapat ditegaskan bahwa sebagai akibat yang paling penting dari prinsip tidak dapat diganggu gugatnya seorang pejabat diplomatik adalah haknya untuk bebas dari yurisdiksi negara penerima dalam kaitannya dengan masalah-masalah kriminal. Jadi dapat dikatakan bahwa kekebalan para diplomat bersifat mutlak dan dalam keadaan apapun mereka tidak boleh diadili ataupun dihukum (Syahmin, loc.cit).

Pengecualian pemberian hak-hak kekebalan diplomatik terhadap tuntutan pengadilan perdata atau sipil mengenai gugatan-gugatan yang berhubungan dengan perkara-perkara profesional dan perdagangan komersial yang dilakukan oleh seorang wakil diplomatik di luar fungsi perwakilannya yang resmi harus dihubungkan dengan Pasal 42 Konvensi Wina 1961 tentang Hubungan Diplomatik (Pasal 42 Konvensi Wina 1961 tentang Hubungan Diplomatik). Hal tersebut memberikan pengertian bahwa di negara penerima seorang wakil diplomatik tidak diperkenankan untuk melakukan kegiatan-kegiatan yang bersifat profesional dan perdagangan komersial untuk mencari keuntungan pribadi (Setyo Widagdo dan Hanif Nur
Widhiyanti, loc.cit). Hal tersebut disebabkan menurut fungsinya sebagai wakil diplomatik dari negara pengirim tidaklah meliputi bidang usaha atau perdagangan yang bertujuan mencari keuntungan pribadi.

Kekebalan dan keistimewaan sebagaimana yang telah dijelaskan tersebut, tentunya dimiliki oleh para perwakilan diplomatik Amerika Serikat yang berada di India, tetapi karena kasus penangkapan yang dilakukan oleh Departemen Luar Negeri Amerika Serikat terhadap Devyani Khobragade yang merupakan wakil Konsulat Jenderal India di Amerika Serikat dengan tuduhan melakukan penipuan atau penyalahgunaan visa dan membuat pernyataan atau dokumen palsu, Pemerintah India kemudian melakukan tindakan pembalasan terhadap perwakilan diplomatik Amerika Serikat yang bertentangan dengan kekebalan dan keistimewaan pejabat diplomatik sebagaimana yang telah dikemukakan sebelumnya dan diatur pada Konvensi Wina 1961 tentang Hubungan Diplomatik.

\section{Pertanggungjawaban Pemerintah India Terhadap Perwakilan Diplomatik Amerika Serikat}

Pertanggungjawaban negara erat kaitannya dengan hak dan kewajiban (Hugh Kindred, 1987:540). Sebagaimana yang dikemukakan oleh hakim Huber bahwa pertanggungjawaban merupakan ikutan atau konsekuensi logis dari sebuah hak (Jawahir Thontowi dan Pranoto Iskandar, op.cit:197). Semua hak yang memiliki karakter internasional mengandung juga 
kewajiban internasional (Malcom N. Shaw, op.cit:542). Tanggung jawab demikian melahirkan kewajiban untuk mengadakan perbaikan (DJ Harris, 1998:486). Karena pertanggungjawaban itu erat kaitannya dengan hak dan kewajiban, maka pada gilirannya melahirkan hukum pertanggungjawaban negara (Lili Rasjidi, 1991:35).

Pertanggungjawaban negara secara internasional dapat dituntut karena ketentuan hukum internasional tentang pertanggungjawaban negara berkaitan dengan suatu keadaan dimana negara yang dilanggar haknya atau dirugikan berhak untuk meminta pertanggungjawaban dan mungkin disertai dengan tuntutan ganti kerugian kepada negara yang melakukan perbuatan atau karena kelalaiannya menimbulkan kerugian pada negara lain (Mohamad Burhan Tsani, op.cit:47). Pasal 1 Draft Articles on Responsibility of States for Internationally Wrongful Acts menjelaskan bahwa setiap perbuatan melawan hukum internasional oleh negara akan menimbulkan tanggung jawab negara secara internasional (Draft Articles on Responsibility of States for Internationally Wrongful Acts).

Perbuatan melanggar hukum adalah perbuatan yang melanggar perjanjian internasional dan kewajiban hukum (Ian Brownlie, 1979:434). Perbuatan melawan hukum internasional dapat diambil dari pengertian wrongful acts yang diartikan sebagai setiap tindakan yang melanggar hak dan merugikan orang lain (Henry Campbell Black,
2007:1110). Dengan kata lain, perbuatan melawan hukum internasional adalah setiap perbuatan negara baik secara langsung maupun tidak langsung yang melanggar hukum internasional atau melanggar kewajiban hukum dan/atau merugikan hak negara lain.

Setiap internationally wrongful acts negara menimbulkan tanggung jawab negara (Pasal 1 Draft articles on Responsibility of State for Internationally Wrongful Acts). Tindakan berbuat atau tidak berbuat (omission) dari negara dapat merupakan internationally wrongful act apabila mengadung unsur dapat dilimpahkan pada negara berdasarkan hukum internasional dan merupakan pelanggaran terhadap kewajiban hukum internasional (breah of an international obligation) (Pasal 2 Draft articles on Responsibility of State for Internationally Wrongful Acts). Karakteristik tindakan negara yang merupakan internationally wrongful act diatur oleh hukum internasional dan tidak dipengaruhi oleh hukum nasional (Pasal 3 Draft articles on Responsibility of State for Internationally Wrongful Acts), artinya sekalipun hukum nasional menyatakan tindakan tersebut sah, tetapi apabila hukum internasional menyatakan sebaliknya maka yang akan berlaku adalah apa yang ditetapkan dalam hukum internasional (Ibid).

Pelanggaran terhadap kewajiban internasional terjadi bila tindakan negara tersebut tidak sesuai dengan yang disyaratkan oleh kewajiban tersebut apapun sifat dan karakternya (Pasal 12 Draft articles on 
Responsibility of State for Internationally Wrongful Acts). Kewajiban hukum internasional dapat muncul dari suatu perjanjian internasional, hukum kebiasaan internasional maupun putusan pengadilan (Sefriani, op.cit:270). Tindakan negara tidak merupakan pelanggaran kewajiban kecuali jika negara tersebut terikat oleh kewajiban yang dipermasalahkan pada saat tindakan terjadi (Jawahir Thontowi dan Pranoto Iskandar, op.cit:199; Pasal 12 Draft articles on Responsibility of State for Internationally Wrongful Acts).

Seperti yang telah dikemukakan pada pembahasan sebelumnya, bahwa latar belakang adanya tanggung jawab negara dalam hukum internasional adalah tidak ada satu negarapun yang dapat menikmati hak-hak negara lain (Huala Adolf, loc.cit). Adanya suatu kewajiban hukum internasional yang berlaku antara dua negara tertentu karena adanya suatu perbuatan atau kelalaian yang melanggar kewajiban hukum internasional, dan adanya kerusakan atau kerugian akibat adanya tindakan yang melanggar hukum atau kelalaian, dan hal tersebut merupakan karakteristik penting yang menimbulkan adanya tanggung jawab negara (Malcom N. Shaw, loc.cit).

Perwakilan diplomatik dalam beberapa hal dijadikan sasaran dari suatu tindakan negara karena statusnya sebagai wakil dari negaranegara dengan kebijakan-kebijakan tertentu atau sebagai tekanan terhadap pemerintah untuk mencapai tujuantujuan politik ataupun juga untuk merusak kredibilitas pemerintah yang sah (Satow's, 1979:176-177; Syahmin, op.cit:122). Terkait dengan tidak dapat diganggu gugatnya gedung perwakilan asing suatu negara pada hakikatnya menyangkut dua aspek. Aspek pertama, adalah mengenai kewajiban negara penerima untuk memberikan perlindungan sepenuhnya kepada perwakilan asing di negara tersebut dari setiap gangguan (Pasal 22 Konvensi Wina 1961 tentang Hubungan Diplomatik). Bahkan bila terjadi keadaan luar biasa seperti putusnya hubungan diplomatik atau terjadi konflik bersenjata antara negara pengirim dan negara penerima, kewajiban negara penerima untuk melindungi gedung perwakilan berikut harta milik dan arsip-arsip harus tetap dilakukan (G. R. Berridge, 1994:34). Aspek kedua adalah kedudukan perwakilan asing itu sendiri yang dinyatakan kebal dari pemeriksaan termasuk barang-barang miliknya dan semua arsip yang ada didalamnya (Pasal 24 dan Pasal 29 Konvensi Wina 1961 tentang Hubungan Diplomatik).

India sebagai negara yang berdaulat telah melakukan pelanggaran terhadap Konvensi Wina 1961 tentang Hubungan Diplomatik sebagaimana yang telah dikemukakan pada pembahasan sebelumnya. Selain itu, India sebagai negara penerima sudah tentu India memiliki kewajiban untuk melindungi seluruh perwakilan asing dari negara pengirim yang sedang berada di negaranya. Kewajiban tersebut tertuang pada Pasal 22 ayat (2) Konvensi Wina 1961 tentang Hubungan Diplomatik yang memberikan kewajiban khusus kepada India sebagai negara penerima untuk mengambil semua tindakan yang patut 
untuk melindungi kantor, gedung atau wisma perwakilan, dari setiap gangguan atau kerusakan dan mencegah setiap gangguan ketenangan perwakilan atau hal yang menurunkan martabat perwakilan diplomatik Amerika Serikat (J. Craig Barker, 2006:66). Hukum internasional telah mengatur bahwa di dalam kedaulatan, terkait di dalamnya kewajiban untuk tidak menyalahgunakan kedaulatan tersebut (Sefriani, loc.cit). Oleh karenanya, Pemerintah India dapat dimintakan pertanggungjawaban untuk tindakan-tindakan atau kelalaiannya yang melawan hukum.

Terdapat sejumlah hal yang menegaskan mengapa Pemerintah India harus bertanggung jawab kepada tindakan pembalasan yang dilakukan terhadap perwakilan diplomatik Amerika Serikat (Ibid). Tindakantindakan Pemerintah India mengandung unsur adanya perbuatan atau kelalaian yang dapat dilimpahkan kepadanya menurut hukum internasional, perbuatan yang dilakukan tersebut merupakan suatu pelanggaran terhadap suatu kewajiban internasional, baik kewajiban itu lahir dari perjanjian maupun dari sumber hukum internasional lainnya dan tindakan melanggar hukum yang dilakukan oleh Pemerintah India tersebut telah menimbulkan kerugian bagi para perwakilan diplomatik Amerika Serikat.

Berkaitan dengan tindakan pembalasan yang dilakukan Pemerintah India terhadap perwakilan diplomatik Amerika Serikat, maka pemerintah India telah dianggap menimbulkan kerugian bagi perwakilan diplomatik Amerika Serikat dengan mencabut beberapa hak istimewa dan kekebalan yang dimiliki oleh perwakilan diplomat Amerika Serikat yang bekerja di India (Australia Network News, 18 Desember 2013), dan meminta semua kartu identitas diplomatik bagi pejabat dan keluarga konsuler Amerika Serikat yang ditempatkan di India untuk dikembalikan kepada Kementerian Luar Negeri India (Foxnews, 18 Desember 2013; (New York Times, 10 Januari 2014). Sehingga, dengan dicabutnya kartu identitas tersebut, kini perwakilan diplomatik Amerika Serikat tidak bisa mempercepat perjalanannya di India (New York Times, 20 Desember 2014), serta akses bagi perwakilan diplomatik Amerika Serikat untuk menuju bandar udara dibatasi oleh Pemerintah India (National Post, 17 Desember 2013).

Tindakan-tindakan sebagaimana dikemukakan tersebut jelas telah melanggar ketentuan hukum internasional sebagaiamana yang dikemukakan sebelumnya, sehingga memenuhi unsur-unsur tanggung jawab negara India untuk mengembalikan hak-hak keistimewaan yang dimiliki oleh perwakilan diplomatik Amerika Serikat agar dapat bergerak bebas untuk menjalankan fungsi resminya sebagaimana diatur pada Konvensi Wina 1961 tentang Hubungan Diplomatik (Mary Mel French, 2010:294).

Menarik barikade polisi yang berada di luar kedutaan besar Amerika Serikat di New Delhi, melepas labirin keamanan berupa beton di luar kedutaan yang dimaksudkan untuk 
melindungi gedung kedutaan tersebut (NBC News, 17 Desember 2013; Washington Post, 12 Januari 2014; Kristina Daugirdas and Julian Davis Mortenson, 2014:327-328), penarikan polisi lalu lintas yang berjaga di sekitar gedung kedutaan (National Post, 17 Desember 2013), dan penjagaan yang kurang pada saat terjadinya demonstrasi di sekitar gedung kedutaan Amerika Serikat (National Post, 19 Desember 2013). Hal tersebut tentunya telah jelas melanggar ketentuan Pasal 22 ayat (2) Konvensi Wina 1961 tentang Hubungan Diplomatik.

Ketentuan pasal tersebut dimaksudkan agar Pemerintah India selaku negara penerima perwakilan diplomatik Amerika Serikat wajib untuk melindungi dan menjaga segala macam bentuk kepentingan negara pengirim seperti mengambil langkah keamanan untuk terlaksananya kegiatan perwakilan diplomatik Amerika Serikat di India. Pemerintah India wajib bertanggung jawab berdasarkan Pasal 22 ayat (2) Konvensi Wina 1961 tentang Hubungan Diplomatik. Selain itu, Konvensi tersebut sudah jelas menyebutkan bahwa negara penerima memang harus bertanggung jawab untuk menjaga seutuhnya keamanan perwakilan di negaranya, serta akibat yang timbul dari perbuatan atau kelalaian negara penerima dalam menjaga perwakilan tersebut.

Hal ini sesuai dengan teori unsurunsur tindakan yang salah dan menimbulkan tanggung jawab negara, yakni ada perbuatan/tindakan (action) atau kelalaian/pengabaian (omission) yang dapat dilimpahkan kepada suatu negara menurut hukum internasional. Seperti yang telah diketahui bahwa aturan-aturan yang tertuang pada Konvensi Wina 1961 tentang Hubungan Diplomatik telah menjadi hukum kebiasaan internasional yang menjadi pedoman bagi setiap negara yang menjalin hubungan diplomatik dengan negara lainnya, sehingga setiap negara yang menjalin hubungan diplomatik wajib tunduk pada ketentuan-ketentuan yang terdapat dalam Konvensi Wina 1961 tersebut (Rasul Yomi Olukolu, Volume 1 Issue 2:5).

Terdapat dua bentuk pemulihan atas pelanggaran hukum internasional yang merugikan negara lain, yaitu satisfaction dan pecuniary reparation. Satisfaction adalah pemulihan atas perbuatan yang melanggar kehormatan negara. Satisfaction dapat dilakukan melalui perundingan diplomatik dan cukup diwujudkan dengan permohonan maaf secara resmi atau jaminan tidak akan terulangnya perbuatan serupa. Pecuniary reparation dilakukan apabila pelanggaran tersebut menimbulkan kerugian materiil, sehingga negara tersebut harus bertanggung jawab sesuai dengan jumlah kerugian materiil yang diderita (F. Sugeng Istanto, op.cit:78-79).

Dalam kaitannya dengan kompensasi yang berwujud materi dapat terdiri dari penggantian biaya pada waktu putusan pengadilan dikeluarkan meskipun jumlah penggantian itu menjadi lebih besar dari nilai pada waktu tindakan pelanggaran kewajiban itu dilakukan (Rhoona K.M Smith, loc.cit). Selain itu, 
dapat juga terdiri dari kerugian tidak langsung (indirect demages), sepanjang kerugian itu mempunyai kaitan langsung dengan tindakan tidak sah tersebut (Sefriani, op.cit:274). Selanjutnya, dapat juga terdiri dari hilangnya keuntungan yang diharapkan sepanjang keuntungan tersebut mungkin dalam situasi atau dalam perkembangan yang normal, serta terdiri dari pembayaran terhadap kerugian atas bunga yang hilang karena adanya tindakan melanggar hukum (Rhoona K.M Smith, dkk, loc.cit).

Pemerintah India yang ingin melakukan pembalasan terhadap tindakan Pemerintah Amerika Serikat yang melakukan pengangkapan terhadap Devyani Khobragade seharusnya tidak melakukan tindakan pembalasan dengan melanggar ketentuan Pasal 50 ayat (2) huruf b Draft Articles on Responsibility of States for Internationally Wrongful Acts. Sesuai dengan ketentuan tersebut, bahwa tindakan pembalasan yang dilakukan suatu negara terhadap negara yang lain juga harus tetap menghormati prinsip tidak dapat diganggu gugatnya agen-agen diplomatik dan konsuler, gedunggedung, arsip serta dokumen perwakilan asing (Pasal 50 ayat (2) huruf b Draft articles on Responsibility of State for Internationally Wrongful Acts; Sefriani, op.cit:280). Sehingga terhadap tindakan-tindakan pembalasan yang dilakukan oleh Pemerintah India terhadap para perwakilan diplomatik Amerika Serikat memunculkan tanggung jawab negara bagi Pemerintah India.
Pasal 48 ayat (2) Draft Articles on Responsibility of States for Internationally Wrongful Acts juga telah secara jelas menetapkan bahwa setiap negara yang berhak untuk meminta pertanggungjawaban dari negara lain, tidak hanya berhak meminta penghentian tindakan pelanggaran serta jaminan tidak mengulangi, tetapi juga berhak atas pemulihan kepentingan-kepentingan negara yang dirugikan dari kewajiban yang dilanggar. Berdasarkan hal-hal yang telah dikemukan tersebut, Pemerintah Amerika Serikat berhak untuk meminta pertanggungjawaban dari Pemerintah India untuk menghentikan pelanggaran yang dilakukan terhadap perwakilan diplomatiknya. Pemerintah India memiliki tanggung jawab untuk melakukan pemulihan terhadap tindakan-tindakan yang dilakukan terhadap perwakilan diplomatik Amerika Serikat, baik dengan cara perundingan diplomatik dan permintaan maaf, serta mengembalikan keadaan seperti semula dengan memberikan kekebalan dan keistimewaan seperti perlindungan terhadap gedung perwakilan dan memberikan kartu identitas yang dimiliki oleh para perwakilan diplomatik sehingga dapat menjalankan fungsi resminya secara efektif dan efisien di India.

\section{Simpulan}

1. Perwakilan Diplomatik Amerika Serikat yang berada di India memiliki kekebalan dan keistimewaan sebagaimana yang diatur dalam Konvensi Wina 1961 tentang Hubungan Diplomatik. 
Seorang pejabat diplomatik berhak mendapat kekebalan dan hak-hak istimewa semenjak ia memasuki wilayah negara penerima, dalam perjalanannya untuk memangku jabatannya, atau jika ia sudah berada di wilayah negara penerima. Seorang pejabat diplomatik tidak dapat diganggu gugat sehingga ia tidak dapat ditahan atau ditangkap oleh alatalat negara penerima. Negara penerima harus memperlakukan mereka secara terhormat.

2. Pemerintah Amerika Serikat berhak untuk meminta pertanggungjawaban dari Pemerintah India untuk menghentikan pelanggaran yang dilakukan terhadap perwakilan diplomatiknya. Pemerintah India memiliki tanggung jawab untuk melakukan pemulihan terhadap tindakan-tindakan yang dilakukan terhadap perwakilan diplomatik Amerika Serikat, baik dengan cara perundingan diplomatik dan permintaan maaf.

\section{Saran}

1. Pmerintah India seharusnya dapat menjamin semua anggota perwakilan Amerika Serikat memiliki kebebasan bergerak dan berpergian di wilayahnya serta kewajiban khusus yang dimiliki untuk mengambil semua tindakan yang patut untuk melindungi gedung perwakilan diplomatik Amerika Serikat dari setiap gangguan atau kerusakan dan melakukan tindakan pencegahan atas segala gangguan yang dapat mengakibatkan ketidaktentraman atau dari segala tindakan yang dapat melecehkan harkat dan martabat gedung perwakilan beserta anggota misinya.

2. Pemerintah India harus bertanggungjawab atas tindakan yang telah dilakukannya dengan mengadakan pemulihanpemulihan berupa pemberian kekebalan dan keistimewaan bagi para perwakilan diplomatik tersebut sebagaimana yang ditentukan dalam Konvensi Wina 1961 tentang Hubungan Diplomatik, sehingga para perwakilan diplomatik dapat melaksanakan fungsi-fungsi resminya secara efektif dan efisien serta hubungan kedua negara agar tetap baik.

\section{Daftar Pustaka}

\section{Buku}

Adolf, Huala, 1991, Aspek-Aspek Negara Dalam Hukum Internasional, RajaGarfindo Persada, Jakarta.

Berridge, G.R., dkk, 2001, Diplomatic Theory from Machiavelli to Kissinger, Palgrave Macmillan, United Kingdom.

Berridge, G. R., 1994, Talking to the Enemy How States without 'Diplomatic Relations' Communicate, Palgrave Macmillan, United Kingdom.

Brownlie, Ian, 1979, Principle of Public International Law, Oxford University Press, United Kingdom.

Barker, J. Craig, 2006, The Protection of Diplomatic Personnel, Ashgate Publishing Limited, England. 
Cornago, Neo, 2013, Plural Diplomacies Normative Predicaments and Functional Imperatives, Martinus Nijhoff Publishers, Leiden, Netherlands.

Dixton, Martin and Robert McCorquodale, 2003, Cases and Material on International Law, Blackstone Press Limited, London.

Dixon, Martin, 2000, Textbook on International Law, Blackstone Press Limited, London.

Effendi, Masyhur, 1993, Hukum Diplomatik Internasional; Hubungan Politik Bebas Aktif Asas Hukum Diplomatik Dalam Era Ketergantungan Antar Bangsa, Usaha Nasional, Surabaya.

Feltham, R.G., 1982, Diplomatic Handbook, Fourth Edition, Longman, London and New York.

French, Mary Mel, 2010, United States Protocol the Guide to Official Diplomatic Etiquette, Rowman \& Littlefield Publishers, United States of America.

Hanitijo, Ronny, 1991, Metode Penelitian Hukum, Cetakan ke II, Ghalia Indo, Jakarta.

Harris, DJ, 1998, Cases and Materials on International Law, Sweet and Maxwell, London.

Istanto, F. Sugeng, 1998, Hukum Internasional, Universitas Atma Jaya, Yogyakarta.

Kusumaatmadja, Mochtar dan Etty R. Agoes, 2010, Pengantar Hukum Internasional, Alumni, Bandung.

Kindred, Hugh, 1987, International Law, Chiefly as Interpreted and Applied in Canada, Emond
Mangovery Publication Limited, Canada.

Mestoko, Sumarsono, 1988, Indonesia dan Hubungan Antar-Bangsa, Sinar Harapan, Jakarta.

McClanahan, Grant V, 1989, Diplomatic Immunity Principles, Pratices, Problems, Georgetown University, Washington DC.

Parthiana, I Wayan, 2003, Pengantar Hukum Internasional, Mandar Maju, Bandung.

Rana, Kishan S., 2013, The Contemporary Embassy: Paths to Diplomatic Excellence, Palgrave Macmillan, United Kingdom.

Rasjidi, Lili, 1991, Filsafat Hukum, Remaja Rosdakarya, Bandung.

Rudy, T. May, 2003, Hubungan Internasional Kontemporer dan Masalah-Masalah Global, Refika Aditama, Bandung.

,2002, Hukum Internasional 1, Refika Aditama, Bandung.

Sefriani, 2010, Hukum Internasional Suatu Pengantar, RajaGrafindo Persada, Jakarta.

Syahmin, 1988, Hukum Diplomatik Suatu Pengantar, Armico, Bandung.

, 2008, Hukum Diplomatik Dalam Kerangka Studi Kasus, PT RajaGrafindo Persada, Jakarta.

Shaw, Malcom N., 1997, International Law, Cambridge University Press, Cambridge.

Smith, Rhoona K.M dkk, 2008, Hukum HAM, Pusham UII, Yogyakarta.

Sharp, Paul, 2009, Diplomatic Theory of International Relations, Cambridge University Press, United Kingdom. 
Suryokusumo, Sumaryo, 2005, Hukum Diplomatik Teori dan Kasus, P.T. Alumni, Bandung.

Suryono, Edy, 1992, Perkembangan Hukum Diplomatik, Mandar Maju, Bandung.

Satow's, 1979, Guide to Diplomatic Practice, 5th, Longman Group, London.

Starke, J.G., 1984, Introduction to International Law, Ninth Edition, Butterworths, London. 2008, Pengantar Hukum Internasional 1, Sinar Grafika, Jakarta.

2007, Pengantar Hukum Internasional 2, Sinar Grafika, Jakarta.

Tsani, Mohamad Burhan, 1990, Hukum dan Hubungan Internasional, Liberty, Yogyakarta.

Thontowi, Jawahir dan Pranoto Iskandar, 2006, Hukum Internasional Kontemporer, Refika Aditama, Bandung.

Widagdo, Setyo dan Hanif Nur Widhiyanti, 2008, Hukum Diplomatik dan Konsuler, Bayumedia Publishing, Malang.

Widodo, 2009, Hukum Diplomatik dan Konsuler Pada Era Globalisasi, Laksbang Justitia, Surabaya. 2012, Hukum Kekebalan Diplomatik, CV Aswaja Pressindo, Yogyakarta.

Konvensi Internasional dan Peraturan-Peraturan Hukum

Konvensi Wina Tahun 1961 tentang Hubungan Diplomatik (Vienna Convention on Diplomatic Relations, 1961, Done at Vienna on 18 April 1961. Entered into force on 24 April 1964. United Nations, Treaty Series, vol. 500, p.95. Copyright United Nations 2005).

Draft articles on Responsibility of State for Internationally Wrongful Acts.

Jurnal dan Karya Tulis Internasional Dahham, Zainab Waheed, The Responsibility of states for protection the diplomatic agents, Business School; LawUniversity of Huddersfield, 1721 Desember 2013.

Daugirdas, Kristina and Julian Davis Mortenson, Contemporary Practice of the United States Relating to International Law, The American Journal of International Law, Volume 118, 2014.

Hassan, Tariq, Diplomatic or Consular Immunity for Criminal Offenses, Virginia Journal of International Law Association, Volume. 2:17, 2011.

Hart, Paul Gully-, The Function of State and Diplomatic Privileges and Immunities in International Cooperation in Criminal Matters: The Position in Switzerland, Fordham International Law Journal, Volume 23, Issue 5, Article 3, 1999.

Higgins, Rosalyn, The Abuse of Diplomatic Privileges and Immunities: Recent United Kingdom Experience, West Law, American Journal of International Law, Cite as: 79 Am. J. Int'l L. 641, 2006. 
Lozancic, Monika, 2009 Diplomatic and Consular Immunities from National Jurisdiction in Criminal Cases-Practice from the Swedish, Dutch and Danish Ministries of Foreign Affairs-, Master thesis, Faculty of Law University of Lund.

Maginnis, Veronica L., Limiting Diplomatic Immunity: Lessons Learned From the 1946 Convention on the Privileges and Immunities of the United Nations, West Law, American Journal of International Law, Cite as: 28 Brook. J. Int'l L. 989, 2008.

Olukolu, Rasul Yomi, Immunity of Foreign Sovereigns, States and Diplomats from Court and Other Processes: An Appraisal of the Nigerian Practice, International Journal of International Law, Volume 1 Issue 2.

Pasqualetti, Gergo, The Screening of the Diplomatic Bag in the light of Recent EU Legislation, Miskolc Journal of International Law, Volume 9, 2012.

Siedell, Emily F., Swarna and Baoanan: Unraveling the Diplomatic Immunity Defense to Domestic Worker Abuse, Maryland Journal of International Law Volume 26, Issue 1, Article 11, 2011.

Tai, Amy, Unlocking the Doors to Justice: Protecting the Rights and Remedies of Domestic Workers in the Face of Diplomatic Immunity, Journal of Gender, Social Policy \& the Law, Volume 16, Issue 1 , Article 4, 2007.
Zabyelina, Yuliya G., The Untouchables: Transnational Organized Crime Behind Diplomatic Intercourse and Immunities, Ecpr General Conference, Bordeaux, 4 - 7 September 2013.

\section{Dokumen-Dokumen}

The United States Department of State Bureau of Diplomatic Security, Diplomatic and Consular Immunity: Guidance for Law Enforcement and Judicial Authorities, URL: http://www.state.gov/documen ts/organization/150546.pdf, diakses pada tanggal 1 Maret 2016.

\section{Kamus}

Henry Campbell Black, 2007, Black's Law Dictionary, St. Paul, Minn: West Publishing Co.

\section{Internet}

Australia Network News, US admits diplomat Devyani Khobragade strip-searched as India launches reprisals over arrest, 18 Desember 2013,

URL: http://www.abc.net.au/news/2 013-12-18/an-india-usdiplomat-arrest/5163076, diakses pada tanggal 13 February 2016.

Ashok Sharma, U.S. denies cavity search claims as Indian government claims diplomat was blackmailed by housekeeper, 19 Desember 2013, URL: http://news.nationalpost.com/n ews/india-demands-that-usdrop-case-against-diplomat- 
who-was-strip-searched-innew-york-city, diakses pada tanggal 2 Maret 2016.

Ellen Barry and Benjamin Weiser, As Indian Diplomat Exits After Arrest, a Culture Clash Lingers, 10 Januari 2014, URL: http://www.nytimes.com/2014 /01/11/world/asia/indiandiplomat-flies-home-afterindictment-in-us.html, diakses pada tanggal 28 Februari 2016.

Foxnews, India retaliates against US over diplomat arrest, removes security barriers at embassy, 18 Desember 2013, URL: http://www.foxnews.com/politi cs/2013/12/18/india-

retaliates-against-us-overarrest-diplomat.html, diakses pada tanggal 1 Maret 2016.

Moni Basu, Indian reaction to diplomat's arrest: Mix of Cold War legacy and politics?, 20 Desember 2013, URL: http://edition.cnn.com/2013/1 2/19/world/asia/indiadiplomat-politics/, diakses pada tanggal 2 Maret 2016.

New York Times, India Tires of Diplomatic Rift over Arrest of Devyani Khobragade, 20 Desember 2014, URL: http://www.nytimes.com/2014 /12/21/world/asia/india-tiresof-diplomatic-rift-overarrest.html, diakses pada tanggal 13 Februari 2016.

Nirmala George, Arrest search of female diplomat in NYC 'despicable and barbaric,' Indian official says, 17 Desember 2013, URL: http://www.nbcnews.com/new s/other/arrest-search-femalediplomat-nyc-despicablebarbaric-indian-official-saysf2D11763458, diakses pada tanggal 2 Maret 2016.

National Post, Arrest and apparent strip-search of Indian consul in New York sees gay spouses of American diplomats threatened in New Delhi, 17 Desember 2013, URL: http://news.nationalpost.com/n ews/arrest-and-apparent-stripsearch-of-indian-consul-in-newyork-sees-gay-spouses-ofamerican-diplomatsthreatened-in-new-delhi, diakses pada tanggal 2 Maret 2016.

Paul D. Shinkman, India Removes U.S. Embassy Barricades in Retaliation for Diplomat's Arrest, 17 Desember 2013, URL: http://www.usnews.com/news /articles/2013/12/17/indiaremoves-us-embassybarricades-in-retaliation-fordiplomats-arrest, diakses pada tanggal 2 Maret 2016.

The Times of India, Who is Devyani Khobragade, 19 Desember 2013, URL: http://timesofindia.indiatimes.c om/india/Who-is-DevyaniKhobragade/articleshow/2765 9238.cms, diakses pada tanggal 13 Februari 2016.

Washington Post, New indictment filed against Indian diplomat Devyani Khobragade in U.S. visa-fraud case, 14 Maret 2014, URL: https://www.washingtonpost.c om/world/asia_pacific/new- 
indictment-filed-against-indiandiplomat-devyani-khobragadein-us-visa-fraudcase/2014/03/14/0074dd80abb0-11e3-adbc888c8010c799_story.html, diakses pada tanggal 13 Februari 2016. 